\title{
Byltingarkenndar framfarir í meðferð lifrarbólgu C Hvers eiga íslenskir sjúklingar að gjalda?
}

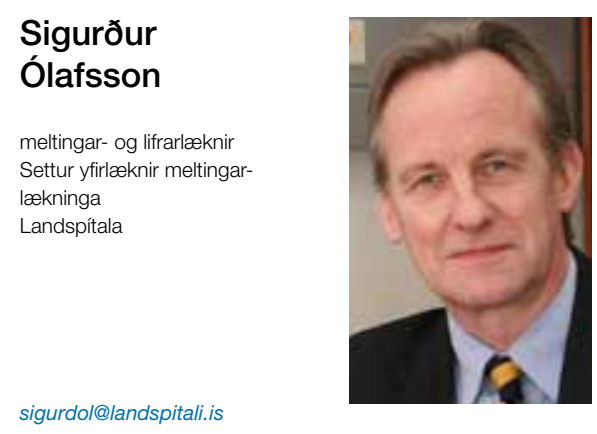

Læknar um allan heim sem meðhöndlað hafa sjúklinga með lifrarbólgu C upplifa nú ævintýralega tíma. Á síðustu misserum hafa komið á markað ný lyf sem lækna langflesta af pessum alvarlega sjúkdómi og hafa jafnframt litlar aukaverkanir. Á sama tíma og pessum sigri læknisfræðinnar er fagnað hefur skuggi hvílt yfir meðferð sjúklinga með lifrarbólgu $C$ hér á landi.

Talið er að um 150.000.000 einstaklinga séu smitaðir af lifrarbólgu $C$ á heimsvísu. Af peim sem smitast fá $20-30 \%$ skorpulifur, gjarnan 20-30 árum eftir smit. Lifrarbólga $C$ er ein algengasta orsök skorpulifrar á Vesturlöndum og algeng ábending fyrir lifrarígræðslu.

Á Íslandi hafa um 1500 einstaklingar greinst með smit af völdum lifrarbólguveiru C. Nokkur hópur hefur fengið lyfjameðferð og læknast. Einnig eru margir úr pessum hópi látnir. Ekki er vitað hversu margir eru með virka sýkingu en áætluð tala er 800-1000 einstaklingar.

Nýgengi skorpulifrar hefur vaxið mjög á undanförnum árum hér á landi og athuganir sýna að lifrarbólga $C$ á par stóran hlut. Að öllu óbreyttu mun pessi sjúkdómur á næstu árum og áratugum verða vaxandi byrði á heilbrigðiskerfi Íslendinga, meðal annars vegna vaxandi fjölda sjúklinga sem mun purfa lifrarígræðslu.

Fjöldi rannsókna hefur sýnt að lyfjameðferð sem upprætir veiruna stöðvar einnig framrás lifrarskemmda. Peir sem eru með sjúkdóminn á frumstigi fá ekki skorpulifur og peir sem eru komnir með skorpulifur geta haldist í stöðugu ástandi til lengri tíma og purfa síður á lifrarígræðslu að halda.
Rúmlega 20 ár eru síðan fyrst var farið að beita lyfjameðferð við pessum sjúkdómi. Hornsteinn meðferðar var lengi vel lyfið interferón-alfa sem sprautað er undir húð. Á fyrstu árum peirrar meðferðar læknuðust innan við 10\% sjúklinga. Með pví að próa meðferðina frekar og bæta við lyfinu ríbavírín var hlutfallið komið um og yfir $50 \%$. Meðferðin varir í 12-24 mánuði og hefur gjarnan miklar aukaverkanir í för með sér.

Árið 2011 komu á markað fyrstu lyfin með beina verkun á lifrarbólguveiru C, prótínasahemlarnir bóseprevír og telaprevír. Pessi lyf voru gefin með interferóni og ríbavíríni og jókst uppræting veirunnar úr um 50\% í 70-75\%. Pví miður voru aukaverkanir gríðarlegar. Síðan hefur próunin verið hröð. Ný kynslóð prótínasahemla er komin í notkun og einnig pólýmerasahemlar og NS5A-hemlar. Lyf úr mismunandi flokkum eru gjarnan notuð í samsettri meðferð tveggja eða fleiri lyfja. Árangur meðferðar fer nokkuð eftir arfgerð veirunnar en sem dæmi má nefna að samsett meðferð með ledipasvír og sófósbúvír (Harvoni ${ }^{\circledR}$ ) í 8-12 vikur leiðir til upprætingar veirunnar í 95100\% tilvika ef um arfgerð 1 er að ræða. Aukaverkanir eru tiltölulega litlar.

Lyfið sófósbúvír (Sovaldi ${ }^{\circledR}$ ) kom á markað í Bandaríkjunum síðla árs 2013 og á síðasta ári á Norðurlöndunum og víðar í Evrópu. Samsetning ledipasvír og sófósbúvír (Harvoni ${ }^{\circledR}$ ) og paritaprevír, ritónavír og ombitasvír (Viekirax $\left.{ }^{\circledR}\right)$ gefið ásamt dasabúvír (Exviera ${ }^{\circledR}$ ) kom á markaðí Bandaríkjunum í nóvember 2014 og er í notkun á Norðurlöndunum. Af öðrum lyfjum má nefna símeprevír $\left(\mathrm{Olysio}^{\circledR}\right)$ og daklatasvír $\left(\right.$ Daklinza $\left.^{\circledR}\right)$. Par sem hin nýju lyf eru dýr er meðferðin víðast hvar takmörkuð, enn sem komið er, við pann hóp sjúklinga sem eru með umtalsverða örvefsmyndun í lifur eða pegar komnir með skorpulifur.

Hver er staðan hér á landi? Hún er sú að í lok maí árið 2015 hafa sjúklingar með lifrarbólgu C, meira að segja peir sem eru komnir með skorpulifur og aðrir í brýnni pörf, ekki aðgang að pessum nýju lyfjum. Jafnvel sjúklingar sem hafa ekki svarað meðferð með eldri lyfjum eiga ekki kost á slíkri meðferð. Öllum umsóknum um markaðssetningu og notkun peirra lyfja sem að ofan er getið er synjað á peirri forsendu að pau rúmist ekki innan ramma fjárveitinga. Pessi staða á sér ekki hliðstæðu í peim löndum sem við viljum helst bera okkur saman við. Ég efast reyndar um að pað eigi sér fordæmi í heilbrigðiskerfi Íslendinga á síðari árum að svo stórum hópi sjúklinga með alvarlegan sjúkdóm sé neitað um jafnáhrifaríka meðferð - meðferð sem íbúum annarra Norðurlandapjóða stendur til boða. Pegar ástandið er rætt við starfsbræður erlendis vekur pað furðu og hneykslan.

Hvernig getur petta gerst hér á Íslandi, hjá pjóð sem flokkast meðal auðugri pjóða í heiminum? Ég ætla ekki í pessari stuttu grein að gera tilraun til að greina rót vandans. Ég hygg að allir sem að heilbrigðispjónustunni koma, hvort sem pað er í heilbrigðisráðuneytinu, innan Sjúkratrygginga Íslands eða á sjúkrastofnunum, hafi að leiðarljósi að Íslendingar geti notið bestu mögulegu heilbrigðispjónustu. Orsakir pess að svona er komið eru vafalítið margvíslegar og kerfislægar og snerta meðal annars hvernig staðið er að ákvarðanatöku um upptöku nýrra lyfja og fjárveitingar til málaflokksins.

Рað sem skiptir mestu máli núna er lausn fáist skjótt pannig hægt sé að hefja meðferð með nýju lyfjunum hjá sjúklingum með lifrarbólgu C, sérstaklega peim sem eru í mjög brýnni pörf, pannig að pessi smánarblettur á okkar samfélagi haldi ekki áfram að stækka.

\section{Heimildir \\ 1. Ward JW. Hepatitis C virus: The 25-year journey from discovery to cure. Hepatology 2014; 60: 1479-82. \\ 2. Ólafsson S, Bergmann Ó, Jónasson JG, Björnsson E. Major increase in the incidence of cirrhosis in Iceland - results of a nationwide populationbasedstudy. Hepatology 2011; 54: Suppl 4: A460.}

Revolution of hepatitis $\mathbf{C}$ antiviral therapy: when will Icelanders gain access to the new drugs? Sigurdur Olafsson, MD, FACP Director of Hepatology, Division of Gastroenterology, Department of Medicine Landspitali University Hospital Reykjavík, Iceland 